\title{
Glaucoma patients not compliant with their drug therapy: clinical and behavioural aspects
}

\author{
PER-ARNE GRANSTRÖM \\ From the Department of Ophthalmology, Huddinge University Hospital, the Karolinska Institute
}

SUMmARY The pattern of drug self-administration among 15 patients not compliant with their pilocarpine therapy was studied with an electronic medication monitor. Recording the date and the hour every time the medication bottle was opened, the monitor gives detailed information on the medication behaviour. The results indicate different types of medication errors: inadequate spacing of doses during the day with long intervals during the night, frequently missed doses at noon, and long interruptions in the medication, sometimes lasting for several days. Improvement in their compliance was seen in patients who were given instruction and taught to relate their medication to specified events in the day.

Noncompliance with prescribed drug regimens has been noted among patients on long-term medication for many chronic diseases, including glaucoma..$^{1-10}$ Unfortunately it is often difficult to compare different investigations owing to the lack' of uniformity in the definitions of compliance. With 2 or more missed doses a week as a definition of non-compliance Bloch et al. ${ }^{7}$ found that $11(28 \%)$ out of 40 patients on drug treatment for glaucoma did not comply with the therapy. In a similar study by Vincent ${ }^{4} 58 \%$ of 62 patients did not adhere to their glaucoma therapy, but in that study only one missed dose a month was permitted for a patient to be termed compliant. In a previous study ${ }^{10}$ we found that $41 \%$ of 82 glaucoma patients on pilocarpine 3 times daily missed 6 or more doses during a 20-day period. An 8-hour dose interval was exceeded at least $20 \%$ of the time by $43 \%$ of the patients.

In comparison with the extensive work on other aspects of compliance with drug therapy little is known about the pattern of drug self-administration. This may be partly due to the lack of appropriate methods of measurement giving objective and detailed information on the medication behaviour. Yee et al. ${ }^{6}$ used a medication monitor to study drug self-administration by 2 glaucoma patients on pilocarpine therapy. Both patients on q.i.d. (4 times daily) prescription missed a large number of doses, and one of them never used the drug more than 3

Correspondence to Dr Per-Arne Granström, Department of Ophthalmology, Huddinge University Hospital, S-141 86 Huddinge. Sweden. times a day during the 3 weeks studied. Except for the morning dose these patients spaced the times of medication during the day rather erratically, with marked variation of dose intervals. Kass reported similar results in a preliminary study of $\mathbf{3 8}$ glaucoma patients. ${ }^{8}$ He also found a wide range between patients in their compliance with the regimen and a considerable variation from day to day in some of them.

The effect of strategies to improve compliance has been evaluated in many clinical trials. The results diverge between different strategies and different settings. ${ }^{11}$ A striking finding is that increasing the patient's knowledge about his illness and its treatment does not always lead to improved compliance. ${ }^{12}$ However, tailoring of doses to 'daily events of a reinforcing nature, may be an important way of helping patients to remember to take their medication. ${ }^{13}$

The purpose of this study was to describe the pattern of drug self-administration by 15 noncompliant patients with open-angle glaucoma (OAG) on pilocarpine therapy and to evaluate the effect of an education and tailoring programme given to 8 of them.

\section{Patients and methods}

\section{METHODS}

Self-medication with pilocarpine eye drops 3 times a day was studied with an electronic medication monitor previously described. ${ }^{14}$ The monitor 


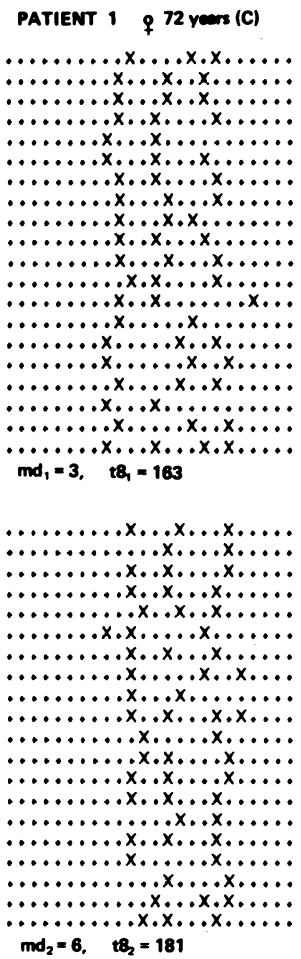

Fig. 1 For legend see Fig. 2.

recorded the date and hour every time the medication bottle was opened during 3 weeks between visits to the eye clinic. The monitor data from the days of the clinic visits were excluded, leaving a record of 20 days. At the end of the first monitor period, patients randomly allocated to a trial group took part in an education and tailoring programme with the aim of improving their compliance. This programme is described elsewhere. ${ }^{15}$ The rest of the patients acted as controls. The medication behaviour of all patients was recorded during a second 20-day monitor period. The patients were interviewed at the end of this period. The interviews earlier described ${ }^{16}$ included the following questions:

(1) How many times a day do you take this drug (pilocarpine)?

(2) How often does it happen that you don't take one of these doses?

(3) How many times did this happen during the past 7 days?

(4) Do you take the eye drops yourself or do you get help from any other person? If Yes to the second part of the question, How often does it occur?

(5) Do you take your eye drops in connection with any special event during the day, the first-secondthird time? If Yes, What special event?
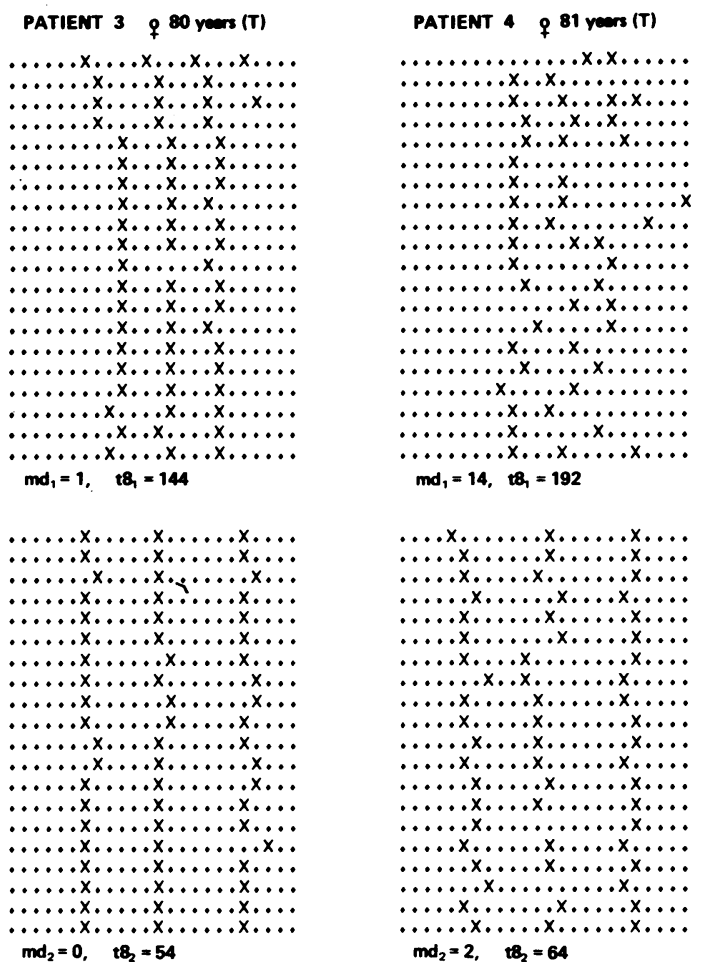

We wanted to get information about spontaneous tailoring of doses among patients included in the trial group, before they went through the education and tailoring programme. Therefore the last question was put to these patients at the end of the first monitor period immediately before the presentation of the programme.

Measurements of intraocular pressure (IOP) were included in a routine clinical examination at the end of the first and second monitor periods. The monitor data from the days of clinic visits, although not shown in the monitor records of this paper, were noted for each patient. With the information on the times for clinic visits the number of hours since the last drug administration could be calculated.

\section{MEASURES OF COMPLIANCE}

The number of missed doses during the first 20-day monitor period $\left(\mathrm{md}_{1}\right)$, was calculated for each patient (that is, the sum of the number of doses less than 3 each day). Dividing this number by 60 (the total number of doses prescribed) gives the proportion of missed doses $\left(\mathrm{pmd}_{1}\right)$.

If all the prescribed doses were taken at equal intervals, the interval length would have been 8 hours. For each patient the time exceeding an 8-hour 


\section{PATIENT 5 \& 80 years (T)}

$\ldots \ldots \ldots \ldots x_{0} x_{0} x_{0} \ldots \ldots \ldots$

$\ldots \ldots \ldots x_{0} \ldots x_{0} \ldots x_{0} \ldots \ldots \ldots$ $\ldots \ldots \ldots x_{0} \ldots x_{0} x_{0} \ldots \ldots \ldots$ $\ldots \ldots \ldots x_{0} x_{0} \ldots x_{0} \ldots \ldots \ldots$ $\ldots \ldots \ldots x_{0} x_{0} \ldots x_{0} \ldots \ldots x_{0}$ $\ldots \ldots x_{0}, \ldots \ldots \ldots \ldots \ldots \ldots$ $\ldots \ldots \ldots x_{0} x_{0} x_{\ldots} \ldots \ldots \ldots$ $\ldots \ldots . . x_{0} \ldots x_{0} \ldots x_{0} \ldots \ldots$ $\ldots \ldots \ldots x_{0} x_{0} \ldots x_{\ldots} \ldots \ldots \ldots$ $\ldots \ldots \ldots x_{\ldots} \ldots \ldots x_{\ldots} \ldots \ldots$ $\ldots \ldots \ldots . . x_{0} \ldots x_{0} \ldots \ldots$ $\ldots \ldots \ldots \ldots x_{0} \ldots x_{0} x_{\ldots} \ldots \ldots \ldots$ $\ldots \ldots \ldots x_{0} \ldots \ldots x_{\ldots} \ldots \ldots \ldots$ $\ldots \ldots \ldots x_{0} \ldots x_{0} x_{1} \ldots \ldots$ $\ldots \ldots \ldots x_{0} x_{0} \ldots x_{\ldots} \ldots \ldots$ $\ldots \ldots \ldots x_{0} x_{0}, x_{\ldots} \ldots \ldots \ldots$ $\ldots \ldots x_{0} \ldots \ldots \ldots \ldots \ldots$ $\ldots \ldots \ldots \ldots x_{0} \ldots x_{\ldots} \ldots \ldots \ldots$ $\ldots \ldots \ldots x_{0} \ldots x_{0} x_{\ldots} \ldots \ldots$ ......... $x_{0} . x_{1}, x_{0} \ldots \ldots \ldots$ $m d_{1}=6, \quad t 8_{1}=181$
PATIENT 6 of 78 years (0)

$\ldots \ldots \ldots x_{\ldots} \ldots x_{\ldots} x_{\ldots} \ldots \ldots$ $\ldots \ldots \ldots x_{0} \ldots x_{0} \ldots x_{0} \ldots \ldots$ $\ldots \ldots \ldots x_{0} \ldots x_{0} \ldots \ldots \ldots \ldots$ $\ldots \ldots \ldots x_{0} . x_{0} \ldots x_{*} \ldots \ldots$ ..................... $\ldots \ldots \ldots x_{\ldots} \ldots x_{0} \ldots x_{\ldots} \ldots \ldots$ $\ldots \ldots \ldots x_{\ldots} \ldots x_{\ldots} x_{\ldots} \ldots \ldots$ $\ldots \ldots \ldots x_{0} \ldots x_{0} . x_{\ldots} \ldots \ldots$ $\ldots \ldots \ldots x_{0} \ldots x_{\ldots} \ldots x_{\ldots} \ldots \ldots$ $\ldots \ldots \ldots x_{0} \ldots x_{0} \ldots x_{0} \ldots \ldots$ .................... $\ldots \ldots \ldots x_{0} \ldots \ldots x_{0} \ldots \ldots \ldots$ $\ldots \ldots \ldots x_{0} \ldots x_{0} . x_{0} \ldots \ldots \ldots$ $\ldots \ldots \ldots x_{0} \ldots x \ldots x_{\ldots} \ldots \ldots$ $\ldots \ldots \ldots x_{\ldots} \ldots x_{\ldots} \ldots x_{\ldots} \ldots \ldots$ $\ldots \ldots \ldots x_{\ldots} \ldots \ldots x_{\ldots} \ldots \ldots$

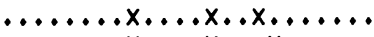
$\ldots \ldots \ldots x_{\ldots} \ldots x_{\ldots} \ldots x_{\ldots} \ldots \ldots$ $\ldots \ldots \ldots x_{\ldots} \ldots x_{0} \ldots \ldots x_{\ldots} \ldots \ldots$ .............. $x_{0} . x_{0} \ldots .$. $m d_{1}=6, \quad t 8_{1}=161$

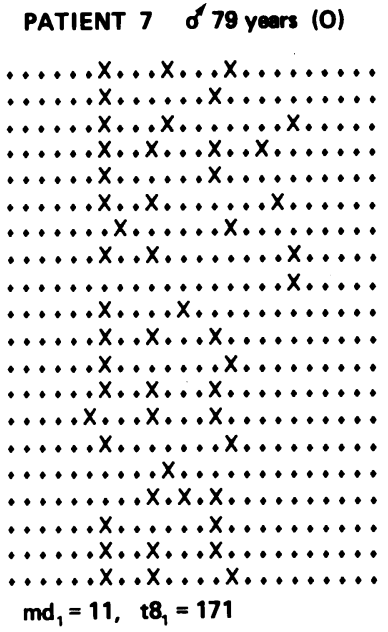

$\ldots \ldots \ldots x_{\ldots} \ldots x_{0} \ldots \ldots x_{\ldots} \ldots$

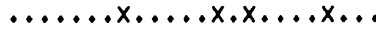
$\ldots \ldots \ldots x_{0} \ldots x_{\ldots} \ldots \ldots x_{\ldots} \ldots$ $\ldots \ldots \ldots x_{0} \ldots x_{0} \ldots \ldots x_{0} . \ldots$ $\ldots \ldots x_{0} \ldots \ldots x_{\ldots} \ldots \ldots x_{\ldots} \ldots$ $\ldots \ldots \ldots x_{0} x_{\ldots} \ldots x_{\ldots} \ldots \ldots x_{\ldots} \ldots$ $\ldots \ldots \ldots x_{\ldots} \ldots x_{0} \ldots \ldots x_{\ldots} \ldots$ $\ldots \ldots x_{0} \ldots x_{0} \ldots \ldots x_{\ldots} \ldots$ $\ldots \ldots \ldots x_{0} x_{0} . x_{0} \ldots \ldots x_{\ldots} \ldots$ $\ldots \ldots \ldots x_{0} \ldots \ldots \ldots \ldots x_{0} \ldots$ $\ldots \ldots \ldots x_{0} \ldots \ldots \ldots \ldots x_{\ldots} \ldots$ $\ldots \ldots \ldots x_{\ldots} \ldots x_{\ldots} \ldots \ldots x_{\ldots} \ldots$ $\ldots \ldots \ldots x_{1} \ldots x_{0} \ldots x_{\ldots} \ldots$ +..................... $\ldots \ldots \ldots x_{\ldots} \ldots x_{\ldots} \ldots \ldots x_{\ldots} \ldots$ $\ldots \ldots \ldots x_{1} \ldots x_{1} \ldots \ldots x_{\ldots} \ldots$ $\ldots \ldots \ldots x_{0} \ldots \ldots x_{0} \ldots \ldots \ldots$

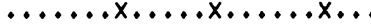
$\ldots \ldots \ldots x \ldots \ldots x_{\ldots} \ldots \ldots x_{\ldots} \ldots$ .................... $\mathrm{md}_{2}=3, \quad t 8_{2}=73$

Fig. 2 Medication with pilocarpine by 15 glaucoma patients on t.i.d. prescription. The upper records represent the first and the lower records the second 20-day monitor periods. Each line represents 24 hours; the first dot on each line corresponds to the first hour after midnight and so forth. An $X$ indicates that the medication bottle was opened at that hour. The letter in brackets indicates whether the patient was included in the trial group $(T)$, in the control group $(C)$, or was lost to the second monitor period $(O)$. The numbers of missed doses $\left(m d_{1}, m d_{2}\right)$ and the times exceeding 8-hour dose interval $\left(t 8_{1}\right.$, $\left.t 8_{2}\right)$ are shown below the first and second monitor records of each patient.

dose interval was calculated for the first 20-day monitor period $\left(t 8_{1}\right)$. Dividing this sum by the length of this observation period gives the proportion of time exceeding 8-hour dose interval ( $\left.\mathrm{pt} \mathrm{8}_{1}\right)$.

\section{PATIENTS}

The study sample included all patients from a previously described series of 82 patients with OAG on $4 \%$ pilocarpine eye drops 3 times a day (t.i.d.), who fulfilled at least one of the following criteria: (1) a proportion of missed doses during the first monitor period of at least $25 \%\left(\mathrm{pmd}_{1} \geq 25 \%\right)$; (2) a proportion of time exceeding an 8-hour dose interval of at least $30 \%$ during the first monitor period ( $\mathrm{pt} \mathrm{8}_{1} \geq 30 \%$ ).

One or both of these criteria were fulfilled by 15 patients. Their ages ranged from 65 to 82 years (median 77 years). Nine were women and 6 were men. The time since glaucoma diagnosis was 7 months to 24 years (median 4 years). Eight of the 15 patients were included in the trial group (who participated in the compliance improving programme), 5 were included in the control group, and 2 were lost from the second recording period owing to defective monitor batteries. One of the latter was unable to participate in the interview.

\section{Results}

Monitor records from the 15 patients are shown in Figs. 1, 2,3, and 4. All patients reported by interview that they were taking pilocarpine 3 times a day. Nine patients always administered the eye drops themselves. Four patients (nos. 3, 5, 6 and 7) were always and 2 (nos. 4 and 10) occasionally helped by some other person. At least 3 different ways of deviation from the 'ideal' medication behaviour can be identified.

(1) Inadequate spacing of doses during the day, 


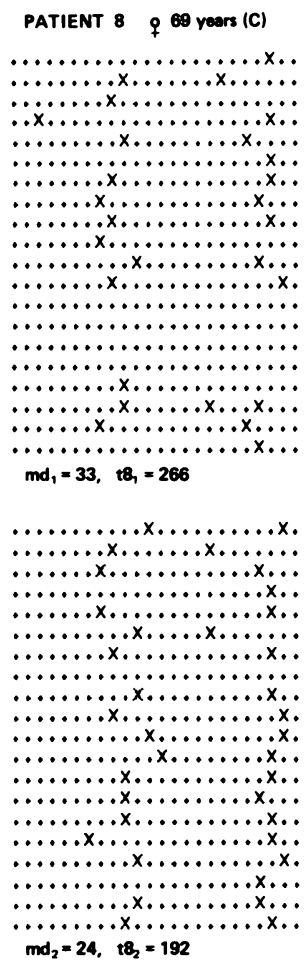

Fig. 3 For legend see Fig. 2.

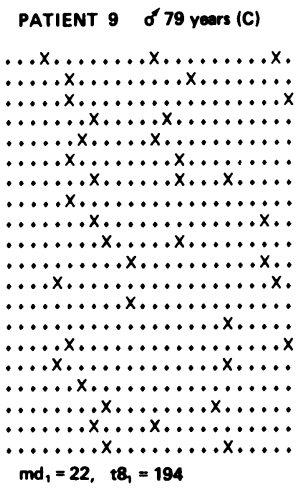

$\cdots \cdots+\cdots, \ldots \ldots \ldots$

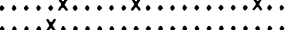

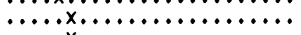

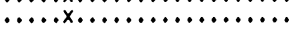

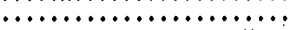

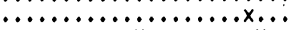
..................... $\ldots \ldots \ldots \ldots \ldots \ldots \ldots \ldots \ldots \ldots$ $\ldots \ldots+\ldots \ldots \ldots \ldots \ldots \ldots$ $\ldots \ldots x_{1} \ldots \ldots \ldots \ldots \ldots \ldots$ $\cdots \ldots \times \ldots \ldots \ldots \ldots \ldots \ldots$ $\ldots \ldots x \ldots \ldots \ldots \ldots \ldots \ldots$ $\ldots \ldots \ldots x_{0} \ldots \ldots \ldots \ldots \ldots$ $\ldots \ldots \ldots \ldots \ldots x_{0} \ldots \ldots \ldots$ $\ldots \ldots x \ldots \ldots . \ldots \ldots \ldots \ldots$ $\ldots \ldots \ldots \ldots \ldots \ldots \ldots \ldots \ldots \ldots$ $\ldots \ldots x_{1} \ldots \ldots x_{1} \ldots \ldots \times x \ldots \ldots$ $\mathrm{md}_{2}=31, \quad \mathrm{t}_{2}=253$

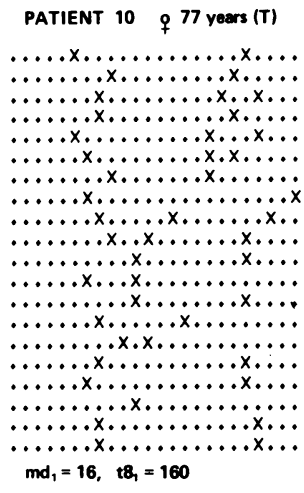

$\ldots \ldots+x \ldots \ldots x \ldots \ldots x_{\ldots} \ldots$ $\ldots \ldots x \ldots \ldots x_{0} \ldots x \ldots$ $\ldots \ldots x_{1} \ldots \ldots \ldots \ldots \ldots x_{n} . \ldots$ $\ldots \ldots \ldots x \ldots \ldots x_{\ldots} \ldots x_{\ldots}$. $\ldots \ldots x_{\ldots} \ldots x_{1} \ldots \ldots x_{\ldots}$. $\cdots \cdots x^{\prime} \cdots \cdots x_{x} \cdots$ $\cdots \cdots x^{\prime} \cdots \cdots x^{\prime} \cdots x^{\prime} \cdots$

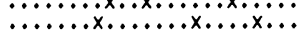
$\ldots \ldots \ldots x_{0} \ldots x_{\ldots} \ldots x_{\ldots} \ldots$

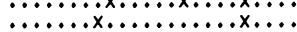

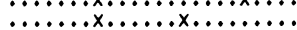
$\ldots \ldots x_{1} \ldots \ldots x_{1} \ldots x_{\ldots}, \ldots$

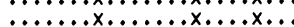

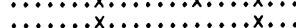

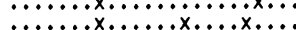

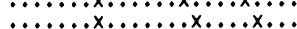
$\ldots \ldots \times x_{1} \ldots \ldots \times x_{\ldots} \ldots \times x_{\ldots} \ldots$

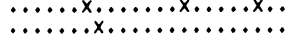

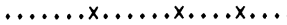
$m d_{2}=7, \quad t 8_{2}=102$

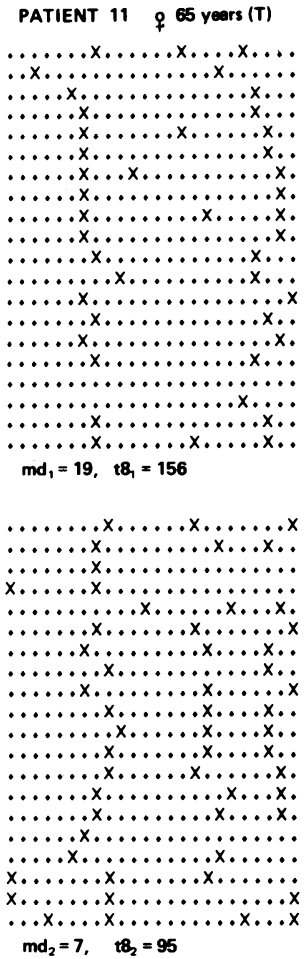

$m d_{2}=7, \quad t B_{2}=95$ with long intervals during the night. This is seen in the records for the first 20-day period from patients nos. 1-7 (Figs. 1 and 2). Most of these patients took almost all their doses during an 8-or 9-hour period in the day with a 15- or 16-hour interval during the night. Patient no. 5 , taking most of her doses during 6 hours, concentrated her medication even more.

(2) Omitting the second (noon) dose. This pattern is seen in the first and second monitor records from patient no. 8 (Fig. 3). During the 40 days recorded this patient took pilocarpine as prescribed 3 times daily on only one day but used the eye drops twice a day on 26 days. Similarly, patients no. 4 (Fig. 1), nos. 9, 10, 11 (Fig. 3), and no. 12 (Fig. 4) missed the second dose on most days of their first monitor periods.

(3) Long interruptions in the medication were seen in 5 patients. As shown in the records from patients no. 2 (Fig. 1), no. 8 (Fig. 3), and nos. 13-15 (Fig. 4), these interruptions may last for several days.

The monitor record from patient no. 7 (Fig. 2) is an example of 'the medication behaviour' by the nursing staff of the long-term care clinic were he lived. In addition to inadequate time separation the doses were scattered, and a large number of doses were missed during the test period (11 out of 60 prescribed).

Most of the 8 patients included in the trial group. who participated in the education and tailoring programme, improved in their medication compliance during the second monitor period. For example, patients no. 3 (Fig. 1) and 5 (Fig. 2), who showed inadequate time spacing during the first monitor periods, separated their doses more evenly during the second periods. Patients 1 and 2 (Fig. 1) from the control group did not change their pattern of drug taking, however. Similarly, patients 10 and 11 (Fig. 3) from the trial group reduced the number of missed second doses, whereas control patients 8 and 9 (Fig. 3) did not. Patient no. 12 (Fig. 4), although she participated in the education and tailoring programme, did not show any improvement. According to her son this patient had a very poor memory. He called her several times during the day to remind her to take the eye drops. Patient no. 13 (Fig. 4) took almost all doses on the days before the clinic visit. He did not participate in the compliance improving programme and repeated his aberrant medication behaviour during the second monitor period. Patients 14 and 15 (Fig. 4) included in the trial 


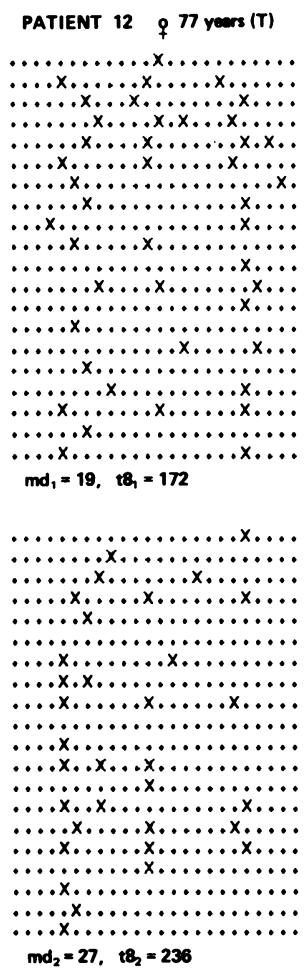

Fig. 4 For legend see Fig. 2.

group showed moderate improvement as their long dose intervals were reduced.

The IOP readings at clinic visits and the time span since the last dose of pilocarpine taken are shown in Table 1 . On all but 5 of the 28 clinic visits the patients had taken the eye drops within 5 hours.

The number of missed doses reported by interview was inaccurately low (Table 2). Of 14 patients interviewed all but one reported that they had not missed a single dose during the past 7 days. Monitor data, however, showed that most of them missed several doses during the same period. Eleven patients reported spontaneous tailoring of doses to some special event in the morning ( 10 patients), during the middle of the day (6 patients), and in the evening (9 patients). The most frequently used events for tailoring were getting up in the morning, eating breakfast and supper, and going to bed.

\section{Discussion}

Some of the patients spacing their doses inadequately seemed to use the drug consistently 3 times a day at almost set times (e.g., patients 3 and 5). In that respect they may be termed compliant but seemed
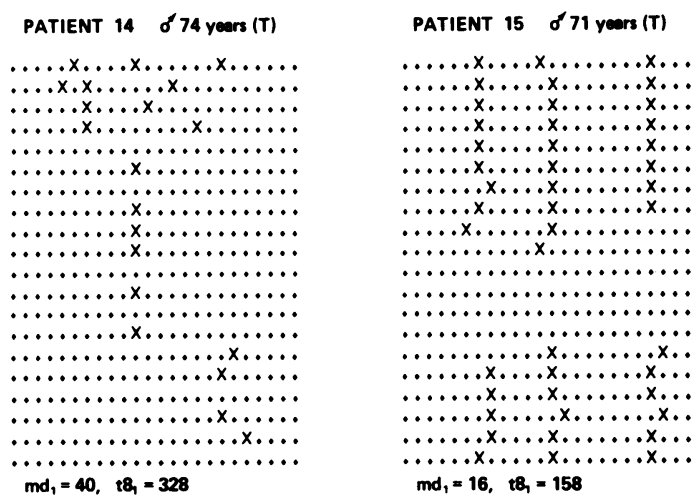

[........... $x \ldots \ldots x_{\ldots} \ldots$ $\ldots \ldots \ldots \ldots x^{\prime} \ldots \ldots \ldots x_{\ldots} \ldots$ $\ldots \ldots \ldots \ldots x_{1} \ldots \ldots \ldots x^{2} \ldots$ $\ldots \ldots \ldots \ldots x \ldots \ldots \ldots x_{\ldots} \ldots$ $\ldots \ldots x_{1} \ldots \ldots x_{0} \ldots \ldots x_{\ldots} \ldots$ ..................... $\ldots \ldots \ldots \ldots \ldots \ldots \ldots \ldots \ldots \ldots \ldots$ $\ldots \ldots \ldots \ldots x_{0} \ldots \ldots x_{\ldots}$ $\ldots \ldots \ldots \ldots \times \ldots \times x_{1} \ldots \ldots$ $\ldots \ldots \ldots \ldots x_{1} \ldots \ldots \ldots x_{n} \ldots$ ..................... .................... $\ldots \ldots \ldots \ldots x_{0} \ldots \ldots \ldots x_{0} \ldots$ $\ldots \ldots \ldots x_{0} \ldots \ldots \ldots \ldots \ldots$ $\ldots \ldots \ldots x_{0} x_{1} \ldots \ldots x_{\ldots} \ldots$

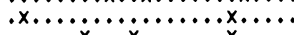
$m d_{2}=19, t 8_{2}=159$ to be on a wrong medication schedule. The incorrect time spacing of doses may be due to inadequate or insufficient information to the patient about the interpretation of the prescription. ${ }^{17}$ Without basic information on pharmacology the patient may not see any reason to separate the doses by equal intervals but may choose the hours of drug administration on some other basis. One patient, for instance, stated that it was easier to remember to take the eye drops if the times for medication were close together.

The second (noon) dose, the most frequently omitted, ${ }^{18}$ seems to constitute a special problem for many patients. The results of the interviews indicate that many patients take their morning and evening doses close to some definite activity such as getting up and going to bed, but they seem to have difficulty in finding a convenient activity to which they can connect the noon dose. Misunderstanding of the number of daily doses prescribed might be another reason for frequently omitted doses. However, this could not apply to the patients in this study, as they all reported that they were taking pilocarpine 3 times a day.

The possible risks of the long dose intervals caused by inadequate time spacing and frequently omitted 
Table 1 Intraocular pressures (IOP) at the end of first (upper 2 figures) and the second (lower 2 figures) monitor periods, and the number of hours within which the last dose of pilocarpine was taken (monitor data).

\begin{tabular}{|c|c|c|c|}
\hline \multirow{2}{*}{$\begin{array}{l}\text { Patient } \\
\text { number }\end{array}$} & \multicolumn{2}{|l|}{$I O P$} & \multirow{2}{*}{$\begin{array}{l}\text { Last dose of } \\
\text { pilo. within }\end{array}$} \\
\hline & $O D$ & $O S$ & \\
\hline 1 & $\begin{array}{l}20 \\
18\end{array}$ & $\begin{array}{l}20 \\
20\end{array}$ & $\begin{array}{l}4 \text { hours } \\
1 \text { hour }\end{array}$ \\
\hline 2 & $\overline{22}$ & $\overline{-}^{*}$ & $\begin{array}{l}4 \text { hours } \\
3 \text { hours }\end{array}$ \\
\hline 3 & $\begin{array}{l}16 \\
14\end{array}$ & $\begin{array}{l}24 \\
26\end{array}$ & $\begin{array}{l}2 \text { hours } \\
4 \text { hours }\end{array}$ \\
\hline 4 & $\begin{array}{l}19 \\
22\end{array}$ & $\begin{array}{l}42 \\
32\end{array}$ & $\begin{array}{l}5 \text { hours } \\
2 \text { hours }\end{array}$ \\
\hline 5 & $\begin{array}{l}12 \\
16\end{array}$ & $\begin{array}{l}16 \\
18\end{array}$ & $\begin{array}{l}3 \text { hours } \\
3 \text { hours }\end{array}$ \\
\hline 6 & $\begin{array}{l}36 \\
38\end{array}$ & $\begin{array}{l}23 \\
23\end{array}$ & $\begin{array}{l}3 \text { hours } \\
-+\end{array}$ \\
\hline 7 & $\begin{array}{r}11 \\
8\end{array}$ & $\begin{array}{r}12 \\
6\end{array}$ & $\begin{array}{l}4 \text { hours } \\
{ }^{+}\end{array}$ \\
\hline 8 & $\begin{array}{l}24 \\
26\end{array}$ & $\begin{array}{l}24 \\
24\end{array}$ & $\begin{array}{l}4 \text { hours } \\
3 \text { hours }\end{array}$ \\
\hline 9 & $\begin{array}{l}33 \\
36\end{array}$ & $\begin{array}{l}44 \\
36\end{array}$ & $\begin{array}{l}5 \text { hours } \\
4 \text { hours }\end{array}$ \\
\hline 40 & $\begin{array}{l}29 \\
26\end{array}$ & $\begin{array}{l}21 \\
26\end{array}$ & $\begin{array}{l}4 \text { hours } \\
13 \text { hours }\end{array}$ \\
\hline 11 & $\begin{array}{l}20 \\
18\end{array}$ & $\begin{array}{l}21 \\
18\end{array}$ & $\begin{array}{l}8 \text { hours } \\
3 \text { hours }\end{array}$ \\
\hline 12 & $\begin{array}{l}12 \\
25\end{array}$ & $\begin{array}{l}12 \\
22\end{array}$ & $\begin{array}{l}7 \text { hours } \\
10 \text { hours }\end{array}$ \\
\hline 13 & $\begin{array}{l}19 \\
18\end{array}$ & $\begin{array}{l}22 \\
20\end{array}$ & $\begin{array}{l}1 \text { hour } \\
4 \text { hours }\end{array}$ \\
\hline 14 & $\begin{array}{l}26 \\
15\end{array}$ & $\begin{array}{l}26 \\
14\end{array}$ & $\begin{array}{l}1 \text { hour } \\
3 \text { hours }\end{array}$ \\
\hline 15 & $\begin{array}{l}13 \\
16\end{array}$ & $\begin{array}{l}13 \\
18\end{array}$ & $\begin{array}{l}4 \text { hours } \\
14 \text { hours }\end{array}$ \\
\hline
\end{tabular}

*IOPs not measured.

t Lost to the second monitor record.

second doses might seem obvious. However, the information on the duration of the IOP lowering effect of pilocarpine is contradictory. The most commonly accepted duration seems to be 6 or 8 hours, ${ }^{1920}$ but some data indicate that the effect may last for 12 or 13 hours, ${ }^{21} 22$ and it may be difficult to predict the consequences.

Long interruptions in the medication may be the most serious type of noncompliance owing to the high proportion of the day without adequate treatment. In addition to the length of these interruptions their frequency will of course also determine their effect on the patient. For instance, patient no. 15 discontinued his medication when having radiotherapy for a tumour in the bladder. There is reason to believe that the break in his medication was exceptional.
Table 2 Number of missed doses during the past 7 days according to interview and monitor, and reported spontaneous tailoring of doses to special events during the day. The letter in brackets indicates whether the patient was included in the trial group $(T)$, in the control group $(C)$, or was lost to the second monitor period $(O)$.

\begin{tabular}{|c|c|c|c|c|c|}
\hline \multirow[t]{2}{*}{$\begin{array}{l}\text { Patient } \\
\text { number }\end{array}$} & \multicolumn{2}{|c|}{$\begin{array}{l}\text { Number of missed doses } \\
\text { during the past } 7 \\
\text { days }\end{array}$} & \multicolumn{3}{|c|}{$\begin{array}{l}\text { Reported spontaneous } \\
\text { tailoring of doses to special } \\
\text { events }\end{array}$} \\
\hline & interview & monitor & morning & noon & evening \\
\hline $1(\mathrm{C})$ & 0 & 3 & + & + & + \\
\hline $2(\mathrm{C})$ & 0 & 8 & - & - & - \\
\hline $3(\mathrm{~T})$ & 0 & 0 & - & - & - \\
\hline $4(T)$ & 0 & 2 & - & - & - \\
\hline $5(T)$ & 0 & 1 & + & + & + \\
\hline $6(0)$ & 0 & - $^{*}$ & + & + & - \\
\hline $7(0)$ & -+ & - $^{*}$ & $t$ & & \\
\hline $8(C)$ & 0 & 8 & + & + & - \\
\hline $9(\mathrm{C})$ & 0 & 8 & + & - & + \\
\hline $10(\mathrm{~T})$ & 0 & 3 & + & - & + \\
\hline $11(\mathrm{~T})$ & 0 & 3 & + & - & + \\
\hline $12(\mathrm{~T})$ & 0 & 8 & + & - & + \\
\hline 13 (C) & 4 & 15 & + & + & + \\
\hline $14(\mathrm{~T})$ & 0 & 6 & + & - & + \\
\hline $15(\mathrm{~T})$ & 0 & 0 & - & + & + \\
\hline
\end{tabular}

* Lost to the second monitor record.

†No interview obtained.

Noncompliant patients with progressive visual field defects or unacceptably high IOPs might undergo needless changes to more potent drugs, with greater risks of severe side effects. A successful filtering operation may solve the problem in some patients. In others glaucoma surgery might be postponed if they show low intraocular pressures when taking the eye drops during the hours before clinic visits.

In clinical work the diurnal curve is sometimes observed to show lower IOP values than measurements in open care units. In these circumstances high IOPs on clinic visits might be assumed to indicate poor adherence to the drug regimen. This is not supported by our findings, however. Although noncompliant, the patients had taken a dose of pilocarpine within 5 hours before most of their clinic visits. Consequently the high IOP values recorded would probably not be due to their poor compliance (Table 1).

The inaccuracy of the interview as a measure of noncompliance (i.e., misşed doses) in this study is in agreement with the findings of others. ${ }^{1623-25}$ However, interview may be valuable in determining the most frequently used times for medication. ${ }^{26}$ Consequently, it may be worth trying to detect patients with inadequate spacing of doses in the clinical work simply by asking them about their times of medication.

The 15 patients of this study were the most non- 
compliant selected among 82 . It might be argued that only a small proportion of the total number deviated seriously from the prescribed regimen. However, some data indicate that compliance will deteriorate with time, ${ }^{1827}$ and the monitor data collected between 2 clinic visits only 3 weeks apart will probably give too optimistic a view of the long-term compliance with medication. Furthermore, the patients studied represent 'survivors' at the clinic, and their compliance might be better than that of an inception cohort. ${ }^{10}$

To evaluate the clinical significance of noncompliance with pilocarpine therapy, long-term monitor studies should be done. There is also a great need for studies of the effect of different dosing of the drug on the progression of the glaucomatous process.

\section{References}

1 Sackett DL, Snow JC. The magnitude of compliance and noncompliance. In: Haynes RB. Taylor DW. Sackett DL, eds. Compliance in Health Care. Baltimore and London: Johns Hopkins University Press, 1979.

2 Riffenburgh RS. Doctor-patient relationship in glaucoma therapy. Arch Ophthalmol 1966; 75: 204-6.

3 Speath GL. Visual loss in a glaucoma clinic. I. Sociological considerations. Invest Ophthalmol Visual Sci 1970; 9: 73-82.

4 Vincent $P$. Factors influencing patient noncompliance: A theoretical approach. Nurs Res 1971; 20: 509-16.

5 Vincent P. Patients' viewpoint of glaucoma therapy. Sight Sav Rev 1972; 42: 213-21.

6 Yee RD, Hahn PM, Christensen RE. Medication monitor for ophthalmology. Am J Ophthalmol 1974; 78: 774-8.

7 Bloch S, Rosenthal AR, Friedman L, Caldarolla P. Patient compliance in glaucoma. Br J Ophthalmol 1977; 61: 531-4.

8 Kass MA. Noncompliance to ocular therapy. Ann Ophthalmol 1978; 10: $1244-5$.

9 Norell SE, Granström P-A. Do glaucoma patients take their pilocarpine eye drops? Transactions of the Swedish Ophthalmological Society 1977. Acta Ophthalmol (Kbh) 1978: 56: 477 .
10 Norell SE, Granström P-A. Self medication with pilocarpine among outpatients in a glaucoma clinic. Br J Ophthalmol 1980; 64: $137-41$

11 Haynes RB. Strategies to improve compliance with referrals. appointments, and prescribed medical regimens. In: Haynes RB Taylor DW. Sackett DL, eds. Compliance in Health Care Baltimore and London: Johns Hopkins University Press, 1979.

12 Sackett DL. Gibson ES, Taylor DW, et al. Randomised clinical trial of strategies for improving medication compliance in primary hypertension. Lancet 1975 ; i: 1205-7.

13 Haynes RB. Gibson ES. Hackett BC, et al. Improvement of medication compliance in uncontrolled hypertension. Lancet 1976 ; i: $1265-8$.

14 Norell SE, Granström P-A, and Wassén R. A medication monitor and fluorescein technique designed to study medication behaviour. Acta Ophthalmol (Kbh) 1980; 58: 459-67.

15 Norell SE. Improving medication compliance: A randomised clinical trial. Br Med J 1979; ii: 1031-3.

16 Norell SE. Accuracy of patient interviews and estimates by clinical staff in determining medication compliance. Soc Sci Med $1981 ; 15: 57-61$.

17 Hermann F. The outpatient prescription label as a source of medication errors. Am J Hosp Pharm 1973; 30: 155-9.

18 Norell SE. Monitoring compliance with pilocarpine therapy. Am J Ophthalmol 1981; 92: 727-31.

19 Ellis P. Ocular Therapeutics and Pharmacology. 5th ed. St Louis: Mosby, 1977: 128-9.

20 Heilmann K. Richardson K. Glaucoma, Conceptions of a Disease. Stuttgart: Thieme, 1978: 272.

21 Drance SM, Bensted M. Schulzer M. Pilocarpine and intraocular pressure. Arch Ophthalmol 1974; 91: 104-6.

22 Quigley HA. Pollack IP. Intraocular pressure control with twicedaily pilocarpine in two vehicle solutions. Ann Ophthalmol 1977; 9: 427-30.

23 Bergman AB, Werner RJ. Failure of children to receive penicillin by mouth. N Engl J Med 1963; 268: 1334-8.

24 Gordis L. Markowitz M, Lilienfeld AM. The inaccuracy in using interviews to estimate patient reliability in taking medication at home. Med Care 1969; 7: 49-54.

25 Roth HP. Caron HS. Accuracy of doctors' estimates and patients' statements on adherence to drug regimen. Clin Pharmacol Ther 1978; 23: 361-70.

26 Alfredsson LS, Norell SE. Spacing between doses on a thricedaily regimen. $\mathrm{Br}$ Med J 1981; 282: 1036-8.

27 Ireland HD. Outpatient chemotherapy for tuberculosis. Rev Resp Dis 1960; 82: 378-83. 